\title{
Physical metallurgy of laser surface melted plastic mould steels: a case study
}

\author{
R. Colaço ${ }^{(*)}$ and R. Vilar ${ }^{(*)}$
}

\begin{abstract}
The purpose of this paper is to illustrate the potential of laser surface melting to improve the surface characteristics of plastic mould steels, using a typical plastic mould steel (DIN X43Cr12) as a case study. After laser surface melting the microstructure of this steel is formed by fine dendrites of austenite partially transformed into martensite. Although the equilibrium solidification phase is $\delta$ ferrite, the formation of primary austenite is kinetically favoured and this phase tends to predominate at the high solidification speeds used in laser processing. It was observed that the volume fraction of retained austenite depends critically on the laser processing parameters, so that the microstructure can change from almost completely martensitic to almost completely austenitic by changing the laser processing parameters. Laser melted tool steels show remarkable secondary hardening after tempering at suitable temperatures. In DIN X42Cr13 the secondary hardening peak temperature after $\operatorname{LSM}\left(600^{\circ} \mathrm{C}\right)$ is $100^{\circ} \mathrm{C}$ higher than after conventional heat treatment $\left(500^{\circ} \mathrm{C}\right)$, due to the presence of large amounts of retained austenite. It was observed that this phase only destabilizes above 600 ${ }^{\circ} \mathrm{C}$, due to the precipitation of $\mathrm{M}_{7} \mathrm{C}_{3}$ and stress relieving. After destabilization, retained austenite transforms into martensite during cooling. Secondary hardening is due to the transformation of retained austenite into martensite and to the precipitation of $\mathrm{M}_{7} \mathrm{C}_{3}$ and $\mathrm{M}_{23} \mathrm{C}_{6}$ carbides.
\end{abstract}

Keywords: Laser surface melting. Tool steel. Microstructure. Retained austenite. Tempering.

\section{Metalurgia física de aceros para moldes de plástico fundidos superficialmente por láser: Un caso práctico}

\begin{abstract}
Resumen El objetivo del presente trabajo es ilustrar el potencial de la fusión superficial mediante láser para la mejora de las características estructurales de los moldes de acero para plásticos, centrándolo en el caso concreto del acero DIN X42Cr13. Tras el tratamiento de fusión superficial mediante láser, la microestructura del material está formada por dendritas finas de austenita parcialmente transformadas en martensita. Aunque la fase en equilibrio sería ferrita $\delta$, la formación de austenita primaria está favorecida cinéticamente, por lo que esta fase tiende a ser predominante a las altas velocidades de solidificación que se consiguen en los tratamientos láser. Se ha observado que la fracción de volumen de austenita retenida depende de manera crítica de los parámetros del procesado con láser, así como que la microestructura puede cambiar de martensita a austenita en función de dichos parámetros. En la fusión superficial del acero DIN X42Cr13 se obtiene un pico de endurecimiento secundario después del tratamiento con láser a $600{ }^{\circ} \mathrm{C}$, mientras que, para los tratamientos térmicos convencionales éste aparece a $500{ }^{\circ} \mathrm{C}$, debido a la presencia de gran cantidad de austenita retenida. El endurecimiento secundario se debe a la transformación de la austenita retenida en martensita y a la precipitación de carburos del tipo $\mathrm{M}_{7} \mathrm{C}_{3}$ y $\mathrm{M}_{23} \mathrm{C}_{6}$.
\end{abstract}

Palabras clave: Fusión superficial por láser. Herramientas. Aceros. Microestructura. Austenita retenida. Revenido.

\section{INTRODUCTION}

Mould steels are supplied either in the pretreated or in the annealed state. In the first case, the microstructure is formed of tempered martensite.

(*) Dpto. de Engenharia de Materiais. Instituto Superior Técnico. Av. Rovisco Pais, 1096, Lisboa (Portugal).
The tempering temperature is such that a sensible compromise between hardness, wear resistance, toughness and machinability is obtained; so these steels are not heat treated after machining. By contrast, annealed steels such as DIN X42Cr13 present a soft microstructure formed of spherodized carbides dispersed in a ferrite matrix, and are quenched and tempered after machining. 
Consequently, the steel can be heat treated to higher hardness than the hardness of pretreated steels allowing longer lifetimes and better service behaviour to be achieved.

Laser surface treatment is particularly well adapted to mould manufacturing, because it often improves significantly surface properties without degradation of bulk characteristics or excessive distortion (1-3). Also, different areas of the same tool may be treated differently to tailor the surface properties to local requirements. Tool steels can be laser hardened by martensitic transformation, leading to a microstructure and hardness similar to those resulting from induction hardening. Since no melting occurs, the process is very energy efficient and distortion is minimal. Nevertheless, due to the short heat treating cycle, large carbide particles cannot dissolve completely and since the hardness of martensite is roughly proportional to its carbon content, hardening may be insufficient. Therefore, laser hardening is only effective in pre-hardened steels or in normalized carbon and low alloy steels. Conversely, processes involving laser surface melting (LSM) lead to complete dissolution of alloy carbides. Due to the high solidification rates involved, the resulting microstructures are fine and frequently contain non-equilibrium phases and supersaturated solid solutions with useful properties (1), including high hardness and good wear and corrosion resistance (4-6). Also, laser surface treatment is particularly well suited to small area treatment, a possibility that does not exist with most other surface engineering methods, but extended area coverage is easily accomplished as well by overlapping laser melted tracks.

The properties of laser melted tool steels depend on the solidification microstructure and on the transformations of solidification phases during cooling down to room temperature. The purpose of this paper is to illustrate the results that can be obtained by $\mathrm{CO}_{2}$ laser surface melting of a plastic mould steel. The correlation between microstructure, properties and processing parameters will be clarified and the principles which govern the formation of microstructure explained. A typical plastic mould steel (DIN $\mathrm{X} 42 \mathrm{Cr} 13$ ) will be used as an example. This material (chemical composition indicated in table I) is supplied in the annealed condition, with a microstructure consisting of $\mathrm{M}_{23} \mathrm{C}_{6}$ and $\mathrm{M}_{7} \mathrm{C}_{3}$ carbides dispersed in a matrix of (-ferrite and with a hardness of $250 \mathrm{HV} 0.2$. A detailed description of these results was reported previously (1 and 7-10).

\section{MICROSTRUCTURE OF THE LASER MELTED MATERIAL}

According to the C-Cr-Fe phase diagram (11), the solidification of a $\mathrm{Fe}-0.47 \mathrm{C}-13 \mathrm{Cr}$ steel should start with the formation of $\delta$-ferrite, followed by the monovariant peritectic reaction $\mathrm{L}+\delta \rightarrow \gamma$ and, finally, by the quasi-peritectic reaction $\mathrm{L}+\delta \rightarrow \gamma+\mathrm{M}_{7} \mathrm{C}_{3}$, but the solidification microstructures show that austenite is the primary solidification phase (1). This discrepancy has recently been explained on the basis of kinetic arguments (7 and 8): under constrained growth conditions, once nucleated, the phase which presents the maximum interface temperature is kinetically favoured (12). In the present case, the solid below the melt pool provides interfaces for epitaxial growth of $\delta$ and $\gamma$, so there is no nucleation barrier and the phase which grows with higher dendrite tip temperature will predominate. Comparison of the calculated dendrite tip temperatures of $\gamma$ and $\delta$ as a function of the solidification rate in the range $10^{-3}$ to $2 \times 10^{-1} \mathrm{~ms}^{-1}$ show that this temperature is higher for $\gamma$ than for $\delta$ in all the solidification speed range ( 7 and 8 ). In practice this means that the equilibrium primary solidification mode will never be observed in laser surface melting of DIN X42Cr13.

The microstructure of the transverse cross section of a laser melted DIN X42Cr13 steel is shown in figure 1 (1). Under the melted layer a heat affected zone (HAZ) is observed, where only solid state transformations occur. The HAZ and the melted layer are separated by a transition zone (TZ) where liquid and solid coexisted during the laser treatment. The thickness of the transition zone will be significant when the thermal gradient is low and the liquidus-solidus temperature interval large, and in this case it may negatively affect the mechanical behaviour of the material. The melted layer is formed by a plane front solidification zone (PFSZ), stabilized near the bottom of the melted layer due to the large $\mathrm{G} / \mathrm{R}$ ratio prevailing during the first stages of solidification, and a cellular-dendritic zone

TABLE I.- Chemical composition of the DIN X42Cr13 steel.

TABLA I.-Composición química del acero DIN X42Crl3 steel.

\begin{tabular}{|l|c|c|c|c|c|c|c|c|c|}
\hline Element & $\mathrm{C}$ & $\mathrm{Cr}$ & $\mathrm{Mo}$ & $\mathrm{Ni}$ & $\mathrm{Si}$ & $\mathrm{Mn}$ & $\mathrm{P}$ & $\mathrm{S}$ & $\mathrm{Fe}$ \\
\hline Weight $\%$ & 0.47 & 12.82 & 0.26 & 0.19 & 0.40 & 0.78 & 0.024 & 0.011 & Bal. \\
\hline
\end{tabular}




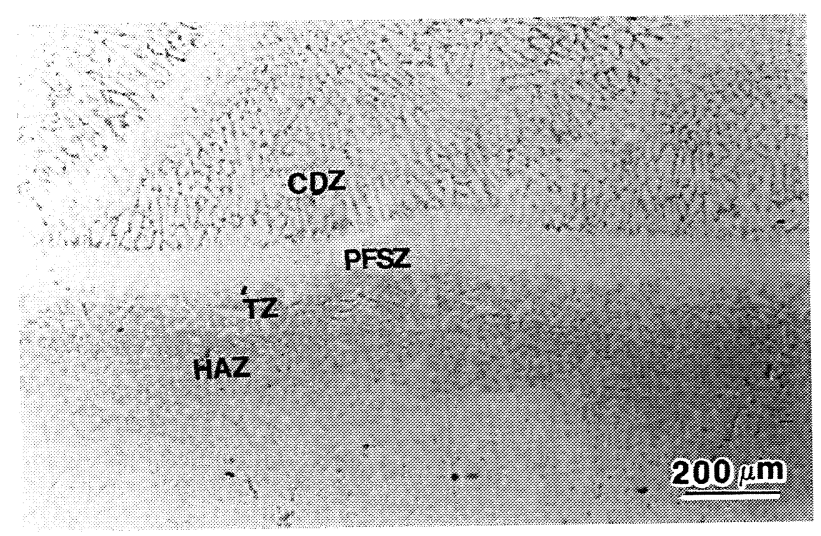

FIG. 1.- Transverse cross section of laser melted DIN X42Cr13 $\left(P=580 \mathrm{~W}, V=6.6 \mathrm{~mm} \cdot \mathrm{s}^{-1}\right.$, Murakami's reagent) (1).

FIG. 1.- Seción transversal de la zona fundida para el acero DIN X24Cr13. $(\mathrm{P}=580 \mathrm{~W}, \mathrm{~V}=6.6$ mm. $\mathrm{s}^{-1}$, Ataque mediante reactivo de Murakami) (1)

(CDZ). The microstructure of the cellular-dendritic zone is formed by fine austenite dendrites partially transfomed to martensite. The primary arm dendritic spacing is within the range 1 to $10 \mathrm{~mm}$ for the laser treatment parameters used, which is in good agreement with the values predicted by solidification theory models (8). Transmission electron microscopy observations showed that martensite is mainly lath-type, though some twinned martensite was also observed and that both martensite and austenite presents a very high dislocation density (1) .

X-ray diffraction analysis showed that the proportion of austenite which transforms to

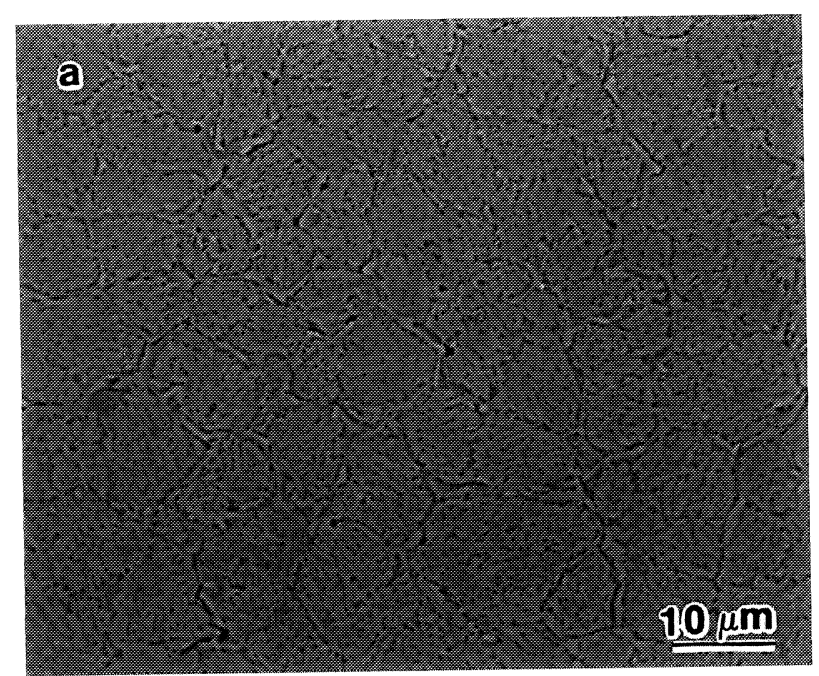

martensite increases with decreasing cooling rate, i.e., with increasing laser power and decreasing scanning speed (9). This behaviour is illustrated in the figures $2 a$ and $2 b$, which show the microstructures of samples treated with the same laser power $(P=2.500 \mathrm{~W})$ and different scanning speeds. The sample treated at $1 \mathrm{mms}^{-1}$ is almost completely martensitic, while the sample treated at $80 \mathrm{mms}^{-1}$ is almost completely austenitic. The parametric dependence of the microstructure of laser surface melted DIN X42Cr13 is shown in figure 3 (9). The mean hardness of the laser melted region varies between 400 and $700 \mathrm{HV}$, depending on the proportion of retained austenite.

\section{TEMPERING BEHAVIOUR}

The presence of large proportions of retained austenite in laser melted tool steels is generally considered to have a detrimental influence on tool steel properties, leading to moderate hardness, unpredictable wear behaviour, risk of cracking during grinding and electrospark machining, and dimensional changes in service (13). The elimination of this phase can be made either by choosing the adequate processing parameters, as previously discussed, or by tempering at a suitable temperature (10). The tempering treatment has the additional advantage of further increasing the hardness of the steel by secondary hardening. Samples of laser surface melted DIN X42Cr13, with approximately $60 \%$ of retained austenite, were submitted to isochronal tempering treatments in a temperature range between 400 and $700{ }^{\circ} \mathrm{C}$. In

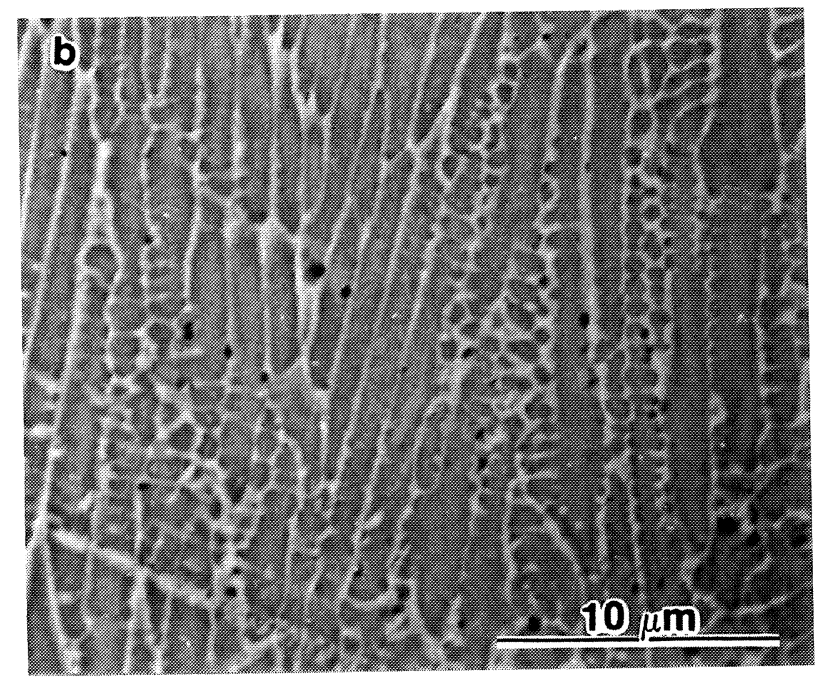

FIG. 2.- Variation of the proportion of retained austenite with the scanning speed. (a) $P=2,500 \mathrm{~W}, V=$ $1 \mathrm{~mm} \cdot \mathrm{s}^{-1}$; b) $P=2,500 \mathrm{~W}, V=80 \mathrm{~mm} \cdot \mathrm{s}^{-1}$ (Villela's reagent)) (9).

FIG. 2.- Variación de la proporción de austenita retenida con la velocidad de procesado. (a) $\mathrm{P}=2.500 \mathrm{~W}$, $\left.\mathrm{V}=1 \mathrm{~mm} \cdot \mathrm{s}^{-1} ; b\right) \mathrm{P}=2.500 \mathrm{~W}, \mathrm{~V}=80 \mathrm{~mm}_{\mathrm{s}} \mathrm{s}^{-1}$ (Ataque mediante reactivo de Villela)) (9). 


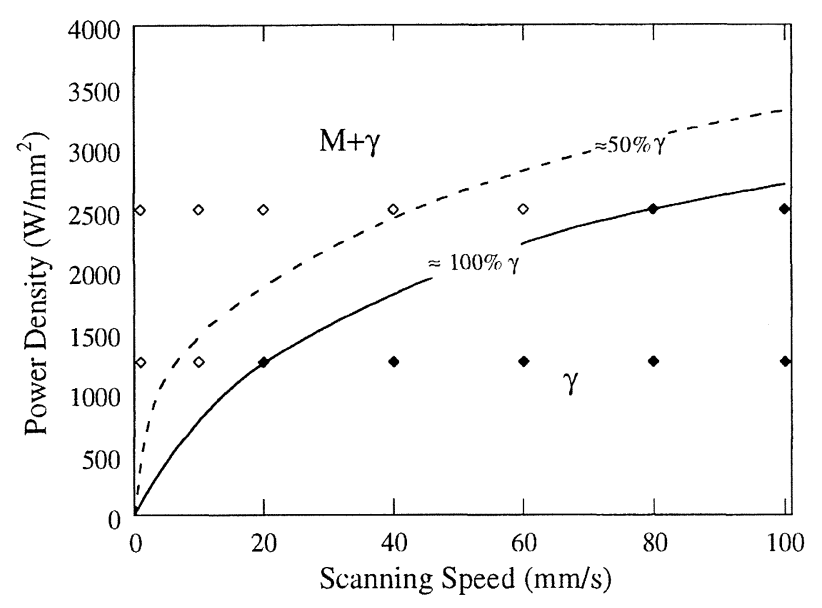

FIG. 3.- Parametric dependence of the microstructure of laser surface melted DIN $\mathrm{X} 42 \mathrm{Cr} 13$ (9).

FIG. 3.- Dependencia de la microestructura con los parámetros de la fusión superficial mediante láser para el acero DIN X42Cr13 (10).

figure 4 , the tempering curve laser surface melted samples is compared with the tempering curve of the same material after conventional quenching from an austenitization temperature of $1,025{ }^{\circ} \mathrm{C}$ (10). It can be observed that the secondary hardening peak temperatures and hardness are 600 ${ }^{\circ} \mathrm{C}$ and $620 \mathrm{HV}$ for laser processed material compared to $500{ }^{\circ} \mathrm{C}$ and $570 \mathrm{HV}$ for the same material after conventional quenching.

In order to understand the causes of the shift for higher temperatures of the secondary hardening peak, sample analysis by differential scanning calorimetry (DSC), X-ray diffraction (XRD) and transmission electron microscopy (TEM) were made (10). It was concluded that the shift in the

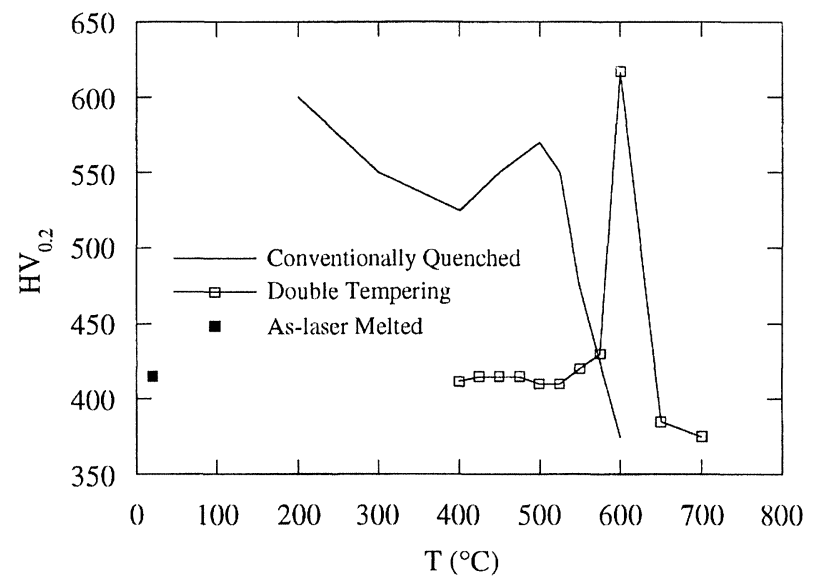

Fig. 4.- Tempering curve of DIN X42Cr13 (10).

FIG. 4.- Curva de revenido para el acero DIN $\mathrm{X} 42 \mathrm{Cr} 13(10)$. secondary hardening peak is closely related to the presence of large proportions of retained austenite in the laser melted material. It was observed that austenite retained in laser melted steels differs from the austenite retained after conventional quenching because, while the latter decomposes during tempering in the $200-350{ }^{\circ} \mathrm{C}$ temperature range for low alloy steels or is destabilized by holding at 500 ${ }^{\circ} \mathrm{C}$ for high alloy steels (14), the former only transforms after tempering at $600{ }^{\circ} \mathrm{C}$. DSC and TEM results showed that the destabilization of austenite retained after laser surface melting occurs only after partial relieving of residual stresses and precipitation of $\mathrm{M}_{7} \mathrm{C}_{3}$ within this phase, leading to a decrease in the solute atoms segregated at dislocations and $M / \gamma$ interfaces. After destabilization, retained austenite transforms to martensite during cooling if the critical cooling rate is exceeded or to ferrite and carbides if the cooling rate is lower. In laser surface melted steel both the carbide precipitation and the transformation of austenite into martensite are responsible for the increase in hardness observed at $600{ }^{\circ} \mathrm{C}$. It is interesting to note that, whereas in conventionally heat treated steels, secondary hardening is mainly due to dispersion hardening by the alloy carbides, in LSM steels the secondary hardening results from the larger extension of the $\gamma \rightarrow \mathrm{M}$ transformation as well as precipitation reactions within austenite and martensite. This may explain the higher hardness of the secondary hardened steel after LSM as compared with the secondary hardness peak after conventional treatment $(620$ and $570 \mathrm{HV}$, respectively). Figure 5 resumes the main differences between the transformation during tempering after conventionally quenching and after laser surface melting.

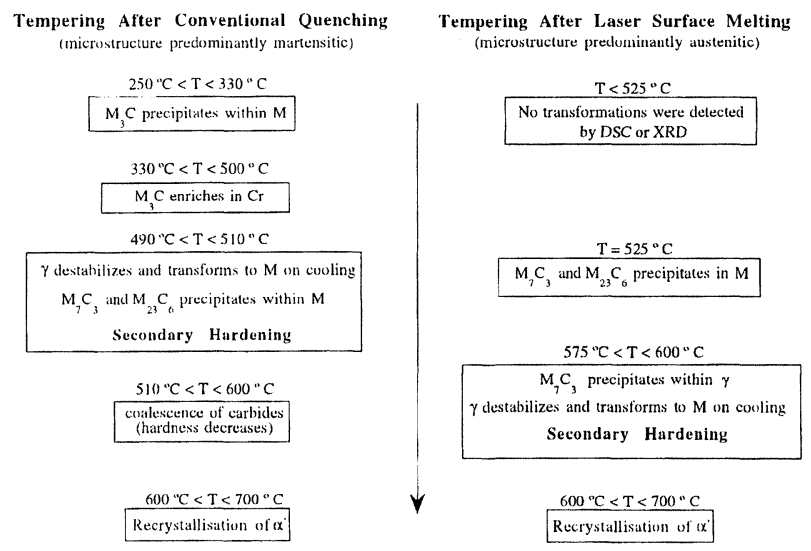

FIG. 5.- Phase transformations during tempering of tool steels.

FIG. 5.- Transformaciones de fase durante el revenido de los aceros para herramientas. 


\section{CONCLUSIONS}

1. LSM improves the properties of tool steels by refining their microstructure, dissolving the carbides, increasing the supersaturation of austenite and martensite, and eliminating inclusions.

2. LSM DIN X42Cr13 frequently contains a large proportion of retained austenite, because the formation of this phase is kinetically favoured at high solidification speed and austenite in LSM tool steels is extremely stable.

3. In LSM DIN X42Cr13 the volume fraction of retained austenite that transforms to martensite depends critically on the laser processing parameters, decreasing with increasing cooling rates.

4. Tempering of LSM DIN X42Cr13 causes intense secondary hardening at temperatures 100 ${ }^{\circ} \mathrm{C}$ higher than after conventional quenching. This shift is due to the presence of large amounts of retained austenite at room temperature, which destabilizes only by tempering at temperatures around $600{ }^{\circ} \mathrm{C}$. Secondary hardening is due to the transformation of retained austenite into martensite and the precipitation of fine carbides within austenite and martensite and at phase and lath boundaries.

\section{REFERENCES}

(1) Vilar, R., Colaço, R. and Almeida, A. NATO ASI E Series, Vol. 307, Kluwer Academic Publ., Dordrecht (Netherlands), 1996: 453-478.

(2) Bell, T., Hancock, I.M. and Bloyce, A. Tool Materials for Molds and Dies, Colorado School of Mines Press, St. Charles (Ill., USA) 1987: 197-216.

(3) Amende, W. LiM5 - 5th Intern. Conf. Lasers in Manufacturing. IFS Publ. Bedford (UK), 1988: 119-125.

(4) Ånman, L. Metall. Trans. 15A, 1984: 1.829-1.935.

(5) Molian, P.A. and Hsu, M.J. Proc. of Surface Modification Technologies II, (T.S. Sudarshan and D.G. Bhat, Eds.). TMS, Warrendale PA (USA), 1988: 155-173.

(6) De Damborenea, J., Marsden, D. West and VazQuez, A. Proc. 9th European Cong: on Corrosion, Utrecht (Netherlands). Fu-172, Ed. by European Federation of Corrosion, 1989.

(7) Colaço, R., VILAR, R. Scripta Mater. 36 (2), 1997: 199205.

(8) Colaço, R. and Vilar, R. Surf. Eng. 12 (4), 1996: 319-315.

(9) Colaço, R. and Vilar, R. Effect of the processing parameters on the proportion of retained austenite in laser surface melted tool steels. J. Mat. Sci. Let. (to be published).

(10) Colaço, R. and Vilar, R. Scr. Mater. 38 (1), 1997: 107113.

(11) Forgeng, W.D. and Forgeng, W.D. Jr. Metals Handbook, Vol. 8. ASM. T. Lyman (ed.). Metals Park (OH, USA) 1973: 402-404.

(12) FRENK, A. and KURZ, W. Lasers in Engineering, 1, 1992: 193-212.

(13) Roberts, G.A. and CARY, R.A. Tool Steels. ASM. Metals Park (OH, USA) 1980.

(14) Honeycombe, R.W.K. and Bhadeshia, H.K.D.H. Steels: Microstructure and Properties, Edward Arnold. London (UK) 1995. 